\title{
Combination of western medicine and Chinese traditional patent medicine in treating a family case of COVID-19
}

\author{
Li Ni ${ }^{1}$, Ling Zhou ${ }^{1}$, Min Zhou ${ }^{2}$, Jianping Zhao ${ }^{2}$, Dao Wen Wang $(\bowtie){ }^{1}$ \\ ${ }^{1}$ Division of Cardiology; ${ }^{2}$ Division of Respiration, Department of Internal Medicine and Hubei Key Laboratory of Genetics and Molecular \\ Mechanisms of Cardiological Disorders, Tongji Hospital, Tongji Medical College, Huazhong University of Science and Technology, Wuhan \\ 430030, China
}

(C) Higher Education Press and Springer-Verlag GmbH Germany, part of Springer Nature 2020

\begin{abstract}
In December 2019, an outbreak of novel coronavirus (2019-nCoV) occurred in Wuhan, Hubei Province, China. By February 14, 2020, it has led to 66492 confirmed patients in China and high mortality up to $\mathbf{2 . 9 6 \%}(1123 / 37$ 914) in Wuhan. Here we report the first family case of coronavirus disease 2019 (COVID-19) confirmed in Wuhan and treated using the combination of western medicine and Chinese traditional patent medicine Shuanghuanglian oral liquid (SHL). This report describes the identification, diagnosis, clinical course, and management of three cases from a family, suggests the expected therapeutic effects of SHL on COVID-19, and warrants further clinical trials.
\end{abstract}

Keywords novel coronavirus (2019-nCoV); COVID-19; Chinese traditional patent medicine; Shuanghuanglian oral liquid

\section{Introduction}

Since December 31, 2019, a cluster of patients with pneumonia of unknown cause has been reported in Wuhan, China. This special pneumonia was associated with a novel coronavirus, 2019-nCoV, named initially by the World Health Organization (WHO) in January 2020 [1]. An outbreak of 2019-nCoV pneumonia (officially and internationally named as COVID-19 on February 11, 2020 by the WHO) occurred and spread to the entire China and multiple countries worldwide [2]. By February 14, the number of patients confirmed with COVID-19 reached 66 492, 8969 suspected patients, and 1523 deaths were identified in China [3]. By February 14, the number of confirmed patients and deaths were 37914 and 1123, respectively, and the mortality of COVID-19 was $2.96 \%$ in Wuhan City, Hubei Province, which is considered as the origin of first cluster of patients [3]. The confusing and difficult thing for physicians is that they do not have specific drugs to either treat or prevent the aggravation and serious complications of COVID-19 for such patients [4]. Thus, Chinese herbs attract our attention, and investigations for different clinical trials are in progress. The present

Received February 16, 2020; accepted February 17, 2020

Correspondence: Dao Wen Wang, dwwang@tjh.tjmu.edu.cn report described a family case, including three cases who received western medicine and Chinese traditional patent medicine Shuanghuanglian oral liquid (SHL) treatments and achieved rapid recovery.

\section{Case report}

The family case includes parents and a daughter. The family lives in an apartment $3 \mathrm{~km}$ from the Huanan Seafood Wholesale Market in Wuhan, Hubei Province. These cases are a typical familial cluster where all of them had COVID-19 [5]. All the patients were informed about the clinical trial (ChiCTR2000029605) and signed informed consent.

Case 1 is a 51-year-old female. On January 17, 2020, the patient presented a feeling of general malaise and coldness. On January 19, she had fever with body temperature of $37.3{ }^{\circ} \mathrm{C}$ and experienced diarrhea and vomiting. She started to receive intravenous injection of cefotaxime in community clinic and took oral Jinyebaidu granules (another Chinese traditional patent medicine) and oseltamivir ( $75 \mathrm{mg}$, twice a day) for 4 days. She had persistent severe fever with body temperature from $37.6{ }^{\circ} \mathrm{C}$ to $38.3{ }^{\circ} \mathrm{C}$ for four days. On January 23 , her chest computed tomography (CT) scan showed multiple patchy ground glass opacity and consolidation shadow in bilateral lung 
and subpleural regions (Fig. 1A). She was highly suspected with COVID-19. Oral moxifloxacin and arbidol were prescribed, and she continued to take Jinyebaidu granules and oseltamivir. On January 24, her body temperature reached $39.9{ }^{\circ} \mathrm{C}$ and experienced severe fatigue, diarrhea, and breathlessness despite continuous treatments of the above drugs. She felt better after intravenous injection of immunoglobin (IVIG, $5 \mathrm{~g}$ per day) and dexamethasone (5 $\mathrm{mg}$, once to twice a day). However, the patient experienced recurrent fever (body temperature of $39^{\circ} \mathrm{C}$ ) and breathlessness, and her blood oxygen saturation fluctuated from $90 \%$ to $95 \%$ at the night of January 27. On January 28, the second chest CT scan indicated that her pneumonia aggravated for the past 5 days (Fig. 1B). A nasopharyngeal swab specimen was obtained and sent for detection of 2019-nCoV. Although the patient's 2019-nCoV test was negative (Table 1), she was diagnosed of COVID-19 in accordance with her symptoms and chest CT display. On the same day, she was confined into an isolation ward and started to take oral SHL (twice a day, $20 \mathrm{~mL}$ once). On the next day, SHL administration increased to three times a day ( $20 \mathrm{~mL}$ once) without using any other drugs. From January 29 to 31, the patient's symptoms resolved with body temperature decreasing from $37.3{ }^{\circ} \mathrm{C}$ to $36.5^{\circ} \mathrm{C}$ and without vomiting and diarrhea. The patient gradually felt strong except for slight cough. After February 6, the patient's symptoms disappeared, and her third chest CT scan (Fig. 1C) showed significant absorption of bilateral ground glass opacity compared with the previous ones. The association of her symptoms with treatments is shown in Fig. 2, and the clinical laboratory results are shown in Table 2.

Cases 2 and 3 became simultaneously ill 9 days after they had close contacts with case 1 [5].

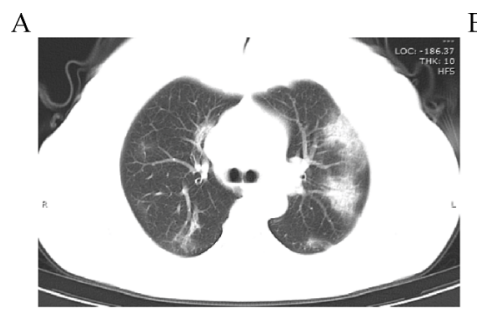

Illness day 7

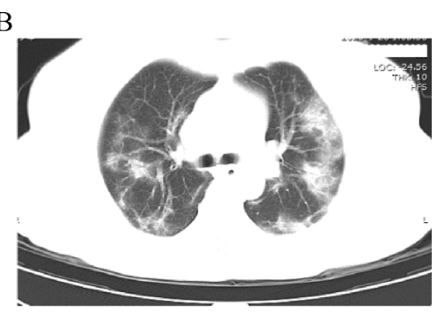

Illness day 12

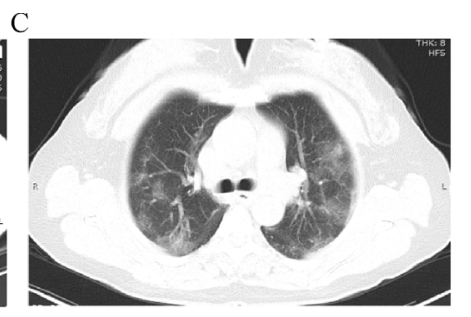

Illness day 22

Fig. 1 Chest CT images of case 1. (A) CT imaging on January 23, 2020 shows ground glass opacity in both lungs on illness day 7. (B) Image taken on January 28, 2020, shows aggravation of pneumonia on illness day 12. (C) Image taken on February 6, 2020 shows the absorption of bilateral ground glass opacity after SHL treatment from January 28.

Table 1 Testing results of 2019-nCoV

\begin{tabular}{|c|c|c|c|c|c|c|c|c|}
\hline \multirow{2}{*}{ Specimen } & \multicolumn{3}{|c|}{ Case 1} & \multicolumn{3}{|c|}{ Case 2} & \multicolumn{2}{|r|}{ Case 3} \\
\hline & Illness day 12 & Illness day 20 & Illness day 23 & Illness day 3 & Illness day 11 & Illness day 14 & Illness day 3 & Illness day 11 \\
\hline Nasopharyngeal swab & Negative & Negative & NT & Negative & Negative & NT & Positive & Negative \\
\hline Anal swab & NT & NT & Negative & NT & NT & Negative & NT & NT \\
\hline
\end{tabular}

NT, not tested.

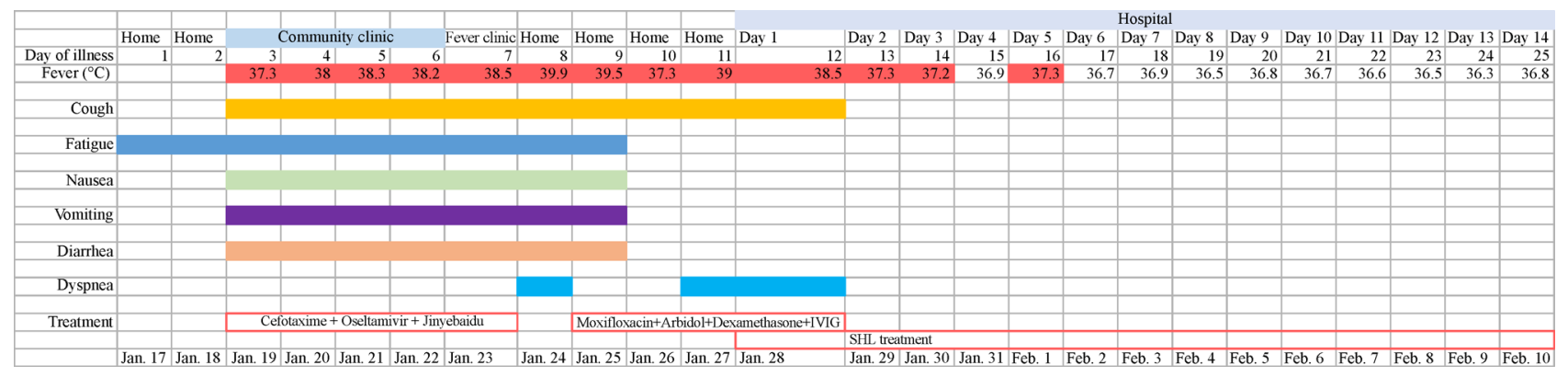

Fig. 2 Symptoms, maximum body temperatures, and treatment timeline in accordance with day of illness and day of hospitalization (January 17 to February 10). 
Table 2 Clinical laboratory results of case 1

\begin{tabular}{|c|c|c|c|}
\hline \multirow{2}{*}{ Measure } & \multirow{2}{*}{ Reference range } & \multirow{2}{*}{$\begin{array}{l}\text { Illness day } 13 \\
\text { Hospital day } 2\end{array}$} & \multirow{2}{*}{$\begin{array}{l}\text { Illness day } 24 \\
\text { Hospital day } 13\end{array}$} \\
\hline & & & \\
\hline White cell count $\left(\times 10^{9} / \mathrm{L}\right)$ & $3.50-9.50$ & 5.93 & 5.46 \\
\hline Red cell count $\left(\times 10^{9} / \mathrm{L}\right)$ & $3.80-5.10$ & 4.13 & 4.06 \\
\hline Neutrophil count $\left(\times 10^{9} / \mathrm{L}\right)$ & $1.90-6.30$ & 3.04 & 3.27 \\
\hline Lymphocyte count $\left(\times 10^{9} / \mathrm{L}\right)$ & $1.10-3.20$ & 2.11 & 1.5 \\
\hline Eosinophil count $\left(\times 10^{9} / \mathrm{L}\right)$ & $0.02-0.52$ & 0.12 & 0.15 \\
\hline Platelet count $\left(\times 10^{9} / \mathrm{L}\right)$ & $125.0-350.0$ & 361 & 323 \\
\hline Hemoglobin $(\mathrm{g} / \mathrm{L})$ & $115.0-150.0$ & 113 & 111 \\
\hline Hematocrit $(\%)$ & $35.0-45.0$ & 35 & 35 \\
\hline Sodium $(\mathrm{mmol} / \mathrm{L})$ & $136-214$ & 140 & 140.4 \\
\hline Potassium (mmol/L) & $3.50-5.10$ & 4.22 & 4.8 \\
\hline Chloride (mmol/L) & $99-110$ & 104.6 & 102.4 \\
\hline Calcium (mmol/L) & $2.15-2.50$ & $2.06 \downarrow$ & 2.19 \\
\hline Carbon dioxide $(\mathrm{mmol} / \mathrm{L})$ & $22.0-29.0$ & $21 \downarrow$ & 25.1 \\
\hline Glucose $(\mathrm{mmol} / \mathrm{L})$ & $4.11-6.05$ & - & 5.01 \\
\hline Blood urea nitrogen $(\mu \mathrm{mol} / \mathrm{L})$ & $2.6-7.5$ & 3.1 & 3.6 \\
\hline Creatinine $(\mu \mathrm{mol} / \mathrm{L})$ & $45-84$ & 53 & 60 \\
\hline Total protein $(\mathrm{g} / \mathrm{L})$ & $64-83$ & 68.4 & 68.6 \\
\hline Albumin $(\mathrm{g} / \mathrm{L})$ & $35-52$ & $29.6 \downarrow$ & $33.2 \downarrow$ \\
\hline Total bilirubin $(\mu \mathrm{mol} / \mathrm{L})$ & $\leqslant 21$ & 6.4 & 4.5 \\
\hline Procalcitonin (ng/mL) & $\leqslant 0.05$ & 0.03 & 0.03 \\
\hline Alanine aminotransferase (U/L) & $\leqslant 33$ & 17 & 20 \\
\hline Aspartate aminotransferase (U/L) & $\leqslant 32$ & 16 & 19 \\
\hline Alkaline phosphatase (U/L) & $35-105$ & 59 & 83 \\
\hline Fibrinogen $(\mathrm{g} / \mathrm{L})$ & $2.00-4.00$ & $5.31 \uparrow$ & - \\
\hline Lactate dehydrogenase (U/L) & $135-214$ & $248 \uparrow$ & - \\
\hline Prothrombin time (s) & $11.5-14.5$ & 13.6 & - \\
\hline International normalized ratio & $0.80-1.20$ & 1.03 & - \\
\hline Creatine kinase (U/L) & $\leqslant 170$ & 35 & 27 \\
\hline C-reactive protein $(\mathrm{mg} / \mathrm{L})$ & $\leqslant 3$ & $57.8 \uparrow$ & - \\
\hline
\end{tabular}

$\downarrow$ The patient's value was below normal. $\uparrow$ The patient's value was above normal.

Case 2 is a 27-year-old female nurse at the clinical trial center of Division of Cardiology of Tongji Hospital, Wuhan, daughter of case 1, who took care of her mother. On January 26, the patient presented mild weakness, diarrhea, and low fever, and she started to take oral Jinyebaidu granules, oseltamivir, moxifloxacin, and arbidol. On the next day, all her symptoms aggravated with body temperature reaching to $38.3^{\circ} \mathrm{C}$, frequent vomiting, and diarrhea for 5 times a day. At the night of January 27, her body temperature reached $39.5^{\circ} \mathrm{C}$ with chest tightness and shortness of breath. Although she took nonsteroidal anti-inflammatory drug (loxoprofen), her fever remained high $\left(39^{\circ} \mathrm{C}\right)$. On January 28 , her chest CT scan showed consolidation shadow in the left lung, and her 2019-nCoV test showed negative using nasopharyngeal swab specimen. Considering her contact history with her mother, she was also confined into an isolation ward and started to take SHL $20 \mathrm{~mL}$ once for three times a day without taking other drugs. Her body temperature ranged from $37.5{ }^{\circ} \mathrm{C}$ to $38.5{ }^{\circ} \mathrm{C}$ during January 29 to 31 and decreased from $37.5{ }^{\circ} \mathrm{C}$ to $36.5{ }^{\circ} \mathrm{C}$ on February 1. All other symptoms resolved on February 2 with recovered appetite and spirit. Two repeated 2019-nCoV tests were negative (Table 1). On February 6, her second chest CT scan showed the absorption of the left lung shadow (Fig. 3). After her disease symptoms disappeared, the oral dose of SHL reduced to $10 \mathrm{~mL}$ once for three times a day. The patient's clinical laboratory results are shown in Table 3.

Case 3 is a 53-year-old male, husband of case 1 and father of case 2, who presented mild diarrhea, vomiting, and fever on January 26. On January 28, the patient was diagnosed of COVID-19 with positive 2019-nCoV test using nasopharyngeal swab specimen (Table 1) and chest CT scan showing patchy ground glass opacity in the right lower lung subpleural fields (Fig. 4). He had no fever, cough, and breathlessness. Thus, the patient started to 


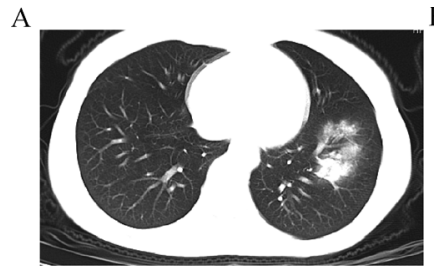

Illness day 3

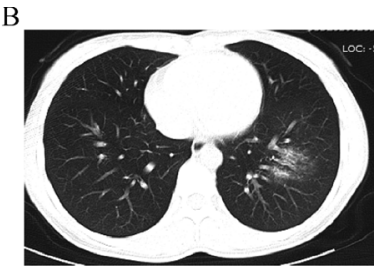

Illness day 13
Fig. 3 Chest CT images of case 2. (A) CT imaging obtained from case 2 on January 28, 2020 shows consolidation shadow in the left lung on illness day 3. (B) Image taken on February 6, 2020 shows the absorption of consolidation shadow after SHL treatment from January 28.

isolate himself at home and took SHL $(20 \mathrm{~mL}$ once, three times a day), moxifloxacin, and arbidol on January 28.
Since February 2, all his symptoms resolved with exception of light nausea, and he continued taking SHL with other drugs. On February 4, he felt slightly weak. On February 7 , the patient fully recovered, and the repeated 2019-nCoV RNA test was negative (Table 1).

\section{Discussion}

This report described the first typical family case of COVID-19 treated using the Chinese traditional patent medicine SHL because of poor response to other treatments. The three patients were a close family, and the mother was the first victim with typical symptoms of severe viral pneumonia and confirmed as COVID-19 in accordance with the symptoms and chest CT scan. Cases 2 and 3 had close contact history with case 1 , and 9 days later

Table 3 Clinical laboratory results of case 2

\begin{tabular}{|c|c|c|c|}
\hline Measure & Reference range & $\begin{array}{l}\text { Illness day } 4 \\
\text { Hospital day } 2\end{array}$ & $\begin{array}{l}\text { Illness day } 15 \\
\text { Hospital day } 13\end{array}$ \\
\hline White cell count $\left(\times 10^{9} / \mathrm{L}\right)$ & $3.50-9.50$ & 3.63 & 5.79 \\
\hline Red cell count $\left(\times 10^{9} / \mathrm{L}\right)$ & $3.80-5.10$ & 4.5 & 4.28 \\
\hline Neutrophil count $\left(\times 10^{9} / \mathrm{L}\right)$ & $1.90-6.30$ & 2.12 & 3.2 \\
\hline Lymphocyte count $\left(\times 10^{9} / \mathrm{L}\right)$ & $1.10-3.20$ & 1.25 & 1.98 \\
\hline Eosinophil count $\left(\times 10^{9} / \mathrm{L}\right)$ & $0.02-0.52$ & 0.01 & 0.17 \\
\hline Platelet count $\left(\times 10^{9} / \mathrm{L}\right)$ & $125.0-350.0$ & 139 & 308 \\
\hline Hemoglobin $(\mathrm{g} / \mathrm{L})$ & $115.0-150.0$ & 125 & 117 \\
\hline Hematocrit (\%) & $35.0-45.0$ & 37.9 & 36.2 \\
\hline Sodium $(\mathrm{mmol} / \mathrm{L})$ & $136-214$ & 135.3 & 143.5 \\
\hline Potassium (mmol/L) & $3.50-5.10$ & 3.69 & 4.27 \\
\hline Chloride (mmol/ L) & $99-110$ & $97 \downarrow$ & 106.3 \\
\hline Calcium (mmol/L) & $2.15-2.50$ & 2.25 & 2.27 \\
\hline Carbon dioxide (mmol/L) & $22.0-29.0$ & 22.3 & 25.2 \\
\hline Glucose $(\mathrm{mmol} / \mathrm{L})$ & $4.11-6.05$ & 4.31 & 4.82 \\
\hline Blood urea nitrogen $(\mu \mathrm{mol} / \mathrm{L})$ & $2.6-7.5$ & 2.7 & 3.4 \\
\hline Creatinine $(\mu \mathrm{mol} / \mathrm{L})$ & $45-84$ & 59 & 52 \\
\hline Total protein $(\mathrm{g} \mathrm{L})$ & $64-83$ & 77.2 & 65.6 \\
\hline Albumin $(\mathrm{g} / \mathrm{L})$ & $35-52$ & 41.5 & 37.5 \\
\hline Total bilirubin $(\mu \mathrm{mol} / \mathrm{L})$ & $\leqslant 21$ & 6.6 & 4 \\
\hline Procalcitonin (ng/mL) & $\leqslant 0.05$ & 0.04 & - \\
\hline Alanine aminotransferase (U/L) & $\leqslant 33$ & 8 & $50 \uparrow$ \\
\hline Aspartate aminotransferase $(\mathrm{U} / \mathrm{L})$ & $\leqslant 32$ & 21 & 27 \\
\hline Alkaline phosphatase (U/L) & $35-105$ & 52 & $22 \downarrow$ \\
\hline Fibrinogen $(\mathrm{g} / \mathrm{L})$ & $2.00-4.00$ & 3.42 & - \\
\hline Lactate dehydrogenase (U/L) & $135-214$ & 170 & 186 \\
\hline Prothrombin time (s) & $11.5-14.5$ & 13.6 & - \\
\hline International normalized ratio & $0.80-1.20$ & 1.03 & - \\
\hline Creatine kinase (U/L) & $\leqslant 170$ & 52 & 27 \\
\hline C-reactive protein $(\mathrm{mg} / \mathrm{L})$ & $\leqslant 3$ & $9.4 \uparrow$ & - \\
\hline
\end{tabular}

$\downarrow$ The patient's value was below normal. $\uparrow$ The patient's value was above normal. 


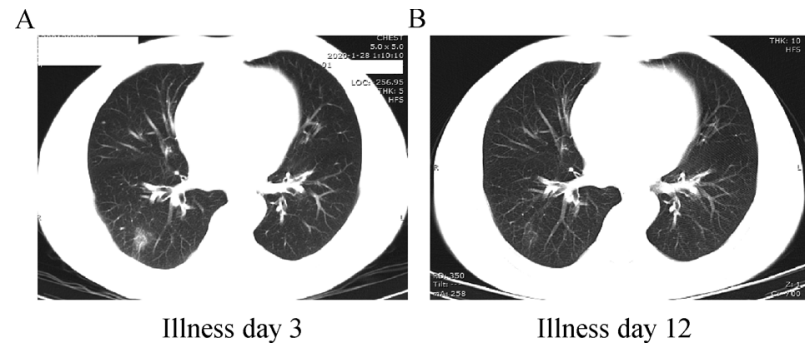

Fig. 4 Chest CT images of case 3. (A) CT imaging obtained from case 3 on January 28, 2020 shows ground glass opacity in the left lung on illness day 3. (B) Image taken on February 7, 2020 shows the absorption of ground glass opacity after SHL treatment from January 28.

they became ill with positive diagnosis of COVID-19. All their symptoms resolved after using the Chinese traditional patent medicine SHL and rapidly recovered without obvious adverse effects when the patients showed no response and their symptoms continued to aggravate after other treatments, including IVIG (5 g per day) and dexamethasone, antibiotics, and antivirus compounds.

SHL, a Chinese traditional patent medicine containing extracts of three Chinese herbs, namely, honeysuckle, forsythia, and Scutellaria baicalensis, is usually used to treat cold, sore throat, and cough with fever. SHL has been used in clinical practice for a long time because of its affordable cost and no serious adverse reaction. Recent news from preliminary study findings indicated that SHL can inhibit 2019-nCoV (http://www.cas.cn/yw/202001/ t20200131_4733137.shtml, accessed on January 31, 2020). Considering that no specific drugs are recommended to treat COVID-19, we started our clinical trial (ChiCTR2000029605) to investigate whether SHL can treat this disease and the family case is a part of the clinical trial. These cases suggest that SHL might be effective for COVID-19 although subsequent clinical trials are needed. In this family case report, we described two patients who had poor response to other treatments but responded well to SHL therapy. Case 3 showed positive therapeutic effect although he simultaneously received arbidol. Early treatments may contribute to patients' outcome and several errors, including taking antibiotics, and combination of two antivirus drugs should be avoided. This report suggests that SHL treatment might be effective for COVID-19 and warrants subsequent clinical trials to obtain sufficient evidence for clinical recommendation.

\section{Acknowledgements}

This work was supported by Tongji Hospital Clinical Research Flagship Program (No. 2019CR207).

\section{Compliance with ethics guidelines}

Li Ni, Ling Zhou, Min Zhou, Jianping Zhao, and Dao Wen Wang declared no potential conflicts of interest with respect to the research, authorship, and/or publication of this article. Informed consent was obtained from all the patients in which their identifying information are included in this article. Other ethical board approval is not applicable in this case report.

\section{References}

1. Zhu N, Zhang D, Wang W, Li X, Yang B, Song J, Zhao X, Huang B, Shi W, Lu R, Niu P, Zhan F, Ma X, Wang D, Xu W, Wu G, Gao GF, Tan W; China Novel Coronavirus Investigating and Research Team. A novel coronavirus from patients with pneumonia in China, 2019. N Engl J Med 2020; 382(8): 727-733

2. Li Q, Guan X, Wu P, Wang X, Zhou L, Tong Y, Ren R, Leung KSM, Lau EHY, Wong JY, Xing X, Xiang N, Wu Y, Li C, Chen Q, Li D, Liu T, Zhao J, Liu M, Tu W, Chen C, Jin L, Yang R, Wang Q, Zhou S, Wang R, Liu H, Luo Y, Liu Y, Shao G, Li H, Tao Z, Yang Y, Deng Z, Liu B, Ma Z, Zhang Y, Shi G, Lam TTY, Wu JTK, Gao GF, Cowling BJ, Yang B, Leung GM, Feng Z. Early transmission dynamics in Wuhan, China, of novel coronavirus-infected pneumonia. N Engl J Med 2020 Jan 29. [Epub ahead of print] doi: 10.1056/NEJMoa2001316

3. National Health Commission of the People's Republic of China. Latest update on Novel Coronavirus Pneumonia as of 24:00, February 14, 2020. 2020. http://www.nhc.gov.cn/xcs/yqtb/202002/ 50994e4df10c49c199ce6db07e196b61.shtml (in Chinese) (accessed February 15, 2020)

4. Holshue ML, DeBolt C, Lindquist S, Lofy KH, Wiesman J, Bruce H, Spitters C, Ericson K, Wilkerson S, Tural A, Diaz G, Cohn A, Fox L, Patel A, Gerber SI, Kim L, Tong S, Lu X, Lindstrom S, Pallansch MA, Weldon WC, Biggs HM, Uyeki TM, Pillai SK; Washington State 2019-nCoV Case Investigation Team. First case of 2019 novel coronavirus in the United States. N Engl J Med 2020 Jan 31. [Epub ahead of print] doi: 10.1056/NEJMoa2001191

5. Chan JF, Yuan S, Kok KH, To KK, Chu H, Yang J, Xing F, Liu J, Yip CC, Poon RW, Tsoi HW, Lo SK, Chan KH, Poon VK, Chan WM, Ip JD, Cai JP, Cheng VC, Chen H, Hui CK, Yuen KY. A familial cluster of pneumonia associated with the 2019 novel coronavirus indicating person-to-person transmission: a study of a family cluster. Lancet 2020; 395(10223): 514-523 